\title{
US OUTWARD FOREIGN DIRECT INVESTMENT IN THE EUROPEAN UNION AND THE IMPLEMENTATION OF THE SINGLE MARKET: EMPIRICAL EVIDENCE FROM A COHESIVE FRAMEWORK
}

\section{INTRODUCTION}

During the last twenty five years the European Union (EU) has been enlarged with the successive waves of accession of 18 new member states, i.e. Greece in 1981, Spain and Portugal in 1986, Austria, Finland and Sweden in 1995, the Czech Republic, Estonia, Latvia, Lithuania, Hungary, Poland, Slovakia, Malta and Cyprus in 2004 and finally Bulgaria and Romania in 2007. The Single Market plan has been put into effect since 1992 and Monetary Union, with the introduction of a single currency (EURO), is also already realised. An argument, related to European integration and the implementation of the Single Market Plan, was that the effects of economies of scale and increased specialisation will not spread equally over the member countries, and thus the less advanced areas may not receive significant benefits in terms of increased efficiency and welfare. «Instead it is claimed, the impact of economies of scale and of agglomeration effects,... will produce self-reinforcing dynamic effects-termed "polarisation" that accentuate rather than ameliorate regional imbalances of real incomes» (Robson, 1987, p. 74). Furthermore, «economies of scale and trade costs encourage the concentration of manufacturing production in countries that have good access to large markets» (Amiti, 1998a, p. 46).

This study follows a macro-economic approach (Aliber, 1970; Froot and Stein, 1991; Grosse and Trevino, 1996; Dunning, 2002; Filippaios et al., 2004). We apply a theoretical framework blending Foreign Direct Investment (FDI) motives of multinational enterprises (MNEs) and macro-economic factors of countries. Similar explanations were proposed by Buckley and Ghauri (2004), Filippaios et al. (2004) and Sethi et al. (2003). Our interest is on the restructuring of FDI activity within EU-15 during the last two decades, and especially before 
and after the implementation of the Single Market Plan in 1992.

Empirical evidence shows that indeed the European integration process changes the locational determinants. Most importantly, though, it has a different effect on core and peripheral countries. The behaviour of US FDI towards the EU has changed through the period under investigation, moving to a more decentralized approach.

The rest of the paper is organized as follows. Section 2 provides the relevant literature and addresses the question from an historical perspective. In the next section, section 3 , we build a theoretical framework and support our hypotheses by providing the relevant literature review. In section 4, we give a brief description of the sample. Section 5 discusses the econometric methods, provides a description of US FDI in EU during the last twenty years and presents the results and their interpretation. Finally, section 6 concludes.

\section{A HISTORICAL PERSPECTIVE OF THE LITERATURE}

At the theoretical and empirical level there has been a long standing tradition of work aiming at measuring the significance of the determinants of US direct investment in the EU. This tradition closely follows the changes, in terms of political and economic matters, that took place within the EU. During the early period, the questions arising were related to the creation of European Economic Community (EEC). It was membership in the EEC and its effect on Foreign Direct Investment (FDI) attraction that was the core of the research agenda. The first effort examining US FDI ${ }^{1}$ in Europe was that of Scaperlanda in 1967. This study, comparing the proportion of long term US FDI in EEC countries and non-EEC countries of Western Europe for the period 1951-1964, concluded that creation of the EEC did not reallocate international investment.

\footnotetext{
${ }^{1}$ US companies' investment in Europe provided the context for a major early wave of studies of determinants of FDI. For summaries and critiques of these see Dunning (1997a,b), Yannopoulos (1990) and Clegg (1996). More recent extensions of analysis of this context include Barrel and Pain (1999a).
} 
During the 1980s and the early 1990s, as the process of European integration evolved, the original question as posed in the 1960s and 1970s was further enriched. It is the effect of the process of deepening the internal market and further economic integration on FDI that comes under investigation. The seminal work of Culem (1988) investigated the bilateral flows of FDI among six industrialised countries for the period 1969-1982. Her results showed that foreign investors prefer "faster growing markets... in relation with the home market of the investor" (p.893) and that high relative unit costs of labour discourage inward FDI.

The accession of Greece in 1981 and of Spain and Portugal in 1985, gave rise to another set of studies stressing the prevalence of both cost and demand considerations. Wheeler and Mody (1992) investigated factors attracting FDI related to agglomeration, i.e. infrastructure quality, degree of industrialisation, existing level of FDI, labour costs and market size.

During the last decade, the creation of the common market enabled firms to capture and exploit economies of scale (Barrell and Pain, 1999a,b) . During the whole period after 1992 there was an intense restructuring of multinational activity provoking the centralisation of production in order to take advantage of the free-trade area. The factors that mainly affected this reorganisation process were closely related to the relevant production and transaction costs and to country specific variables. We can summarise this reorganisation activity in two forces:

The first one is the realisation of economies of scale in a number of industries. As Dunning (1997a) suggests, a wider market makes it possible to segregate various functions of an industry into specialised undertakings that will themselves constitute new industries. The second reason is more dynamic and is put forward by Barell and Pain (1999b, p. 925) who argue: "The potential for agglomerations to attract new investments which then influence the growth process has important implications for national policies, as it means that the size of nations is to be determined in the process of European integration, not just taken as given." 
Finally, Davis and Weinstein (1999) suggested that economic geography could provide a substantial insight into production at a regional level, giving reasonable answers to the restructuring of multinational activities within EU. The changes in multinational activity during this period are directly addressed by Egger and Pfaffermayr (2004). In their study they investigate three main events: the impact of the completion of the Single Market, the enlargement of 1995 and, finally, the agreements of EU with the Central and Eastern European Countries (CEECs). They found positive effects on FDI attraction deriving from all three events. In another study measuring the impact of increased integration on multinational activity, Clegg and Scott-Green (1999) suggest that “...increased economic integration is positively evaluated by enterprises, and our analysis of EC92 shows that the effects of European Integration on FDI can be significant." In this study we further expand their argument.

The question is then readdressed in a theoretical framework built by Neary (2002). He argues that the reduction of internal barriers might have two distinct effects. On the one hand it may lead to increased competition within the EU and thus force MNEs to relocate activities in an efficiency-seeking way (Dunning, 1993). On the other hand, the dismantling of trade barriers may lead to a concentration of economic activity and production in certain regions and then from there serve the rest of the union. In a similar way the analysis of Buch et al. (2003) studies the redirection of FDI in Europe from the Southern countries to the CEECs. They conclude that there is no redistribution of FDI activity at this point.

\section{THEORETICAL BACKGROUND AND HYPOTHESES}

We build on three previous studies to formulate a theoretical framework that will enable us to provide straight and clear answers on the impact of the process of EU integration during the last two decades on the determinant factors of FDI attraction. 
At the heart of the analysis are Buckley and Ghauri (2004) who declare that MNEs' strategies "revolve around the ability of MNEs to subdivide their activities more precisely and to place them in the optimal location". A similar interpretation of MNEs' strategies and of countries' evolution of locational characteristics can be found in Sethi et al. (2003). Their main argument is that by bringing together economy-wide factors and strategic motives of firms, undertaking FDI decisions, we can get a clear picture of the changing pattern of multinational activity. In this paper we also follow closely the analysis by Filippaios et al. (2004) and address FDI as the way MNEs continuously expand and restructure their activities. MNEs are configured as 'dynamic differentiated networks' in response to global competition and their need to achieve and maintain their competitive position. This network of operations is subject to expansion to new markets, i.e. countries, regions, and to restructuring of already established subsidiaries and roles as the firm's needs alter or host country's characteristics are reinterpreted. Various typologies of strategic imperatives have been proposed in the literature. Sethi et al. (2003) consider increased competition, search for new low-cost locations, firm's rival moves and government actions. Hejazi and Pauly (2003) discuss motivations in terms of market access, factor endowment differences and access to natural resources. Here we use a tripartite typology of FDI motives following Behrman (1984) and Dunning (1993, 2000). This typology is closely related to the process of EU integration during the last two decades and to particular aspects of host countries.

Originally, the first US FDI in the EU was motivated by the need of US firms to enter the "Fortress Europe" (Neary, 2002). The firms wanted to take advantage of the dismantling of trade barriers within the EU. This behaviour is closely related to the Market Seeking (MS) motivation of FDI. EU markets were sufficiently prosperous to consume US products and, at the same time, the high levels of trade protection made it profitable to invest and serve the local or contiguous markets rather than export. This MS behaviour has been challenged by 
freer trade and the various multilateral agreements of EU with other countries. Wallis (1968), D’Arge (1969), Scaperlanda and Mauer (1969), Schmitz (1970), Goldberg (1972) and Schmitz and Bieri (1972) further enriched the original question of reallocation of US FDI (Scaperlanda, 1967) by investigating which factors eventually determine FDI in Europe. Among the variables tested were tariff discrimination, market size and growth rates. The results for the first decades following the Second World War were not consistent, changing from one study to another. One of the first studies that extended the time period into the late seventies was performed by Scaperlanda and Balough (1983). Market size and growth potential of the host economy now emerged as consistently significant among other factors. These early studies mainly elaborated the decision of US firms to invest in Europe based on the grounds of the integrated market and primarily the desire to get inside the tariff wall. As the process of European Integration progresses we expect MS motives to remain of particular importance, especially for core countries which constitute the major markets. In this study we use two measures of MS behaviour capturing primarily production aspects of the MS motivation $^{2}$ :

Gross Domestic Product (GDP) captures the most direct relation between the market size of a country and FDI. A larger market, in terms of demand, makes the realisation of economies of scale in production more possible and thus favours FDI servicing rather than export (Venables 1999; Vernon, 1966). Various studies use GDP as a core determinant in MNEs' decision to invest with the underlying hypothesis of a positive sign (Braunerhjelm and Svenson, 1996; Cullem, 1988; Barell and Pain, 1996; Wheeler and Mody, 1992; Veugelers, 1991). This leads to our testable hypothesis:

\footnotetext{
${ }^{2}$ Alternatively someone could use consumer indicators of Market Seeking behaviour such as GDP per capita or Consumer Buying Power. These indicators show a high correlation coefficient with the GDP and the GDP
} 
HIa: We expect a positive relationship between GDP and US FDI.

Gross Domestic Product Growth Rate (GDPGR) acts complementary to the absolute market size (Cullem, 1988; Veugelers, 1991). This variable captures the MS behaviour in a rather more long-term horizon. High growth rates indicate the potential of the local economy both in terms of future market size as well as improved economic conditions.

H1b: A positive relation between GDPGR and US FDI is hypothesised.

At the same time this MS motivation was joined by a second one taking the form of Efficiency Seeking (ES). This motivation constitutes the restructuring of FDI within EU. The process of European integration and expansion created new opportunities for firms to upgrade or reinforce their competitive advantages. Relocation of specific activities serves the main objective to produce cost efficiently. These were primarily export-oriented activities from lower-cost locations, perhaps countries belonging to the European Periphery. This constitutes the emergence of the 'differentiated network' (Filippaios et al. 2004). In this strand of literature, Cushman $(1985,1987)$ studying US inflows and outflows with other industrialised countries, reported that "a rise in source country wages or cuts in its labour productivity encourages FDI out of that country" (Cushman 1985, p.181). Similar explanations on FDI determinants were given by various studies published in the late 1980s or early 1990s (Pain, 1993; Papanastassiou and Pearce, 1990; Veugelers, 1991). In this paper we measure ES behaviour using the following variables: 


\section{Compensation of employees (LCOST) and labour productivity in the business sector}

(LPROD) are at the heart of ES motives. The relation between wages, productivity and FDI is clear (Pain, 1993). Wage has been found to have a stable negative relation with FDI, while the opposite holds for productivity (Cushman, 1987). Especially after the realisation of Single Market Plan, the increased competition within EU forced MNEs to restructure and relocate their operations in search of lower production costs. These two variables represent a strongly attractive factor for ES FDI. The inclusion of labour productivity in the business sector serves as a broader indicator of labour market conditions. Our hypothesis is that LCOST will be negatively related with FDI representing the need for lower labour cost and thus cost efficiency, whilst LPROD will be positively related to FDI, accounting for better labour market conditions and quality of labour force. The application of these two variables is very common in the FDI studies (Barrel and Pain, 1996, 1999a,b; Cullem, 1988; Wheeler and Mody, 1992; Veugelers, 1991)

H2a: A negative relation exists between LCOST and US FDI.

H2b: A positive relation exists between LPROD and US FDI.

Openness (OPEN) as defined by exports over total trade, could be either substituting or complementing for FDI (Markusen 1984; Dunning, 1997a,b; Torstensson, 1998). This variable, accompanied by the Relative Export Price Index (EXPRI), describes the competitiveness position of a country in terms of international trade and exposure. Two dimensions of these variables need to be stressed here. High level of competitiveness accompanied with price advantages can support FDI strategies aiming at wider markets than the country itself. In the context of EU this can be translated as another aspect of MS behaviour. Concentration of production in the most efficient location but still targeting the 
whole region is the most pervasive depiction of this investment behaviour.

H2c: A positive relation between OPEN and US FDI is expected.

H2d: A positive relation between EXPRI and US FDI is expected.

Both MS and ES motives can explain a large part of the restructuring in FDI within EU during the last two decades. They represent ways in which MNEs can exploit their mature competitive technologies. A third motivation, however, goes beyond traditional and mature products and technologies. It focuses on the way FDI activities seek to secure their long-term competitiveness. The increased dispersion of the sources from which firms can acquire inputs in the creative or learning process led to Knowledge Seeking (KS) motives. Financing R\&D and augmenting the quality of labour constitute one of the reinforcing elements of agglomeration. Following Symeonides (1996) we also distinguished between « innovative inputs» and «innovative outputs», measuring the former with Business Expenditure on R\&D (BERD) and the latter with the number of patents registered by each host-country (TRPAT). We consider patents as a more efficient measure of R\&D activity, as it demonstrates the effective use of technological inputs such as $R \& D$ expenditures and/or number of scientific and technological personnel, etc. We would expect US firms to not rely exclusively on home R\&D resources, but to capitalize on the advance technological capabilities of host economies (Papanastassiou and Pearce, 1999).

Total Patents are the direct indicator of the ability of the host economy to produce new knowledge and efficiently involve in research and development activities. The ability of countries to generate knowledge and thus attract knowledge seeking MNEs is proposed by Kogut and Chang (1991) and Neven and Siotis (1996). 
H3a: A positive relation is expected between TRPAT and US FDI.

On the other hand Business Expenditure on R\&D can be an indicator of local firms' abilities in competing. Increased competition might lead firms out of certain markets or countries. The effect of BERD on MNEs decisions is thus not a direct one. A knowledge seeking MNE might invest in an economy with high BERD, aiming at externalities from local firms. The relationship of BERD and FDI can therefore be either positive or negative.

H3b: The relationship between BERD and US FDI can be either positive or negative.

Finally to control for agglomeration factors and cultural differences between the different countries, we also augmented our model with two more variables.

The lagged variable of FDI stock (FDIP[-1]) is capturing agglomeration factors related to the existence of previous FDI in the country or region under investigation. There is a clear positive relation hypothesised between current and previous stock of FDI (Bellak and Cantwell, 2004).

H4a: There is a strong positive relationship between the FDIP[-1] and US FDI.

The percentage of pupils that learn English in the Lower and Upper Secondary education (CULT) is also included in the model. Cultural similarities are an important factor for FDI decisions. Edwards and Buckley (1998) showed that Australian manufacturers invested predominantly in the UK because of the perceived similarity to the Australian environment. Culture comprises various aspects and can be fluid across time and space. To capture the different dimensions, i.e. time and space, we included a language learning variable which functions as a proxy for cultural differences. In a previous study Veugelers (1991) 
found a positive influence of language on FDI decisions ${ }^{3}$.

H4b: There is a positive relationship between CULT and US FDI.

Finally our dependent variable FDIP captures the FDI position (stock) of US investors in country $i$ at time $t$. In the literature there is an ongoing debate as to whether stocks or flows should be used in order to capture the investors' motivations. In this paper we used the stock values for two basic reasons. Firstly, due to the dynamic model we estimate we would like to have stock of FDI, which captures agglomeration aspects as well, rather than its changes from period to period. The estimation method is better operationalised with the use of stocks as it produces first differences in order to provide the results. A description of the econometric technique is presented in section 5. Following our hypotheses we derived the following estimable equation:

$$
\begin{aligned}
& \text { FDIP }_{i, t}=a_{0}+b_{1} \text { FDIP }_{i, t-1}+b_{2} \text { GDP }_{i, t}+b_{3} \text { GDPGR }_{i, t}+b_{4} \text { LCOST }_{i, t}+b_{5} \text { LPROD }_{i, t}+ \\
& +b_{6} \text { COMP }_{i, t}+b_{7} \text { EXPRI }_{i, t}+b_{8} \text { BERD }_{i, t}+b_{9} \text { TRPAT }_{i, t}+\text { CULT }_{i, t}+u_{i}+\varepsilon_{i, t}
\end{aligned}
$$

Where $i=1,2, \ldots, 14$ represents country $i$ and $t=1982,1983, \ldots, 2002$ the time period.

\section{DATA SAMPLE DESCRIPTION}

Our sample of countries, i.e. hosts to US FDI, covers the first 15 members of the EU during the period investigated, from the early 1980s (1982) to the early 2000s (2002). We intend to pursue a deeper insight into FDI decisions within the EU through distinguishing between core and peripheral groups of countries (in terms of differences in economic characteristics). ${ }^{4}$ The

\footnotetext{
${ }^{3}$ Another point that should be made here is related to our econometric technique. Arellano-Bond estimator does not allow for time invariable variables thus we had to find a time varying measure of culture.

${ }^{4}$ Some special cases were also examined to provide further support to our results and arguments and also test the results' consistency. Results for those cases alongside some arguments are presented in Appendix 1. Nordic countries, i.e. Sweden and Finland, became members in 1995 thus we decided to estimate FDI determinants
} 
peripheral group contains those EU member states that mainly participate in the European Structural Funds Programme (ESFP) and the Cohesion Funds Programme, i.e. Greece, Italy, Ireland, Portugal and Spain. The dependent variable tested in the analysis is annual US direct investment stocks in individual EU countries ${ }^{5}$.

Data was compiled from various issues of a number of Eurostat and OECD publications, including the 'Main Economic Indicators', 'Main Science and Technology Indicators', 'International Trade and Competitiveness Indicators', 'International Investment Statistics Yearbook' and Eurydice Database. This range of publications and databases facilitated the coverage of the relevant economic variables and the extended time frame. Table 1 summarises the variables used and the relevant sources.

Insert table 1 here.

\section{ECONOMETRIC TECHNIQUES, RESULTS AND INTERPRETATION}

\section{5.a. Econometric Techniques}

The introduction of a lagged independent variable capturing agglomeration economies involves the problem of correlation of error terms with common specifications (fixed effects models) (Hsiao, 1986). Then the Least Square Dummy Variable (LSDV) is biased even for a moderate time period. Consequently, one has to apply an instrumental variables estimation technique to sweep out the correlation problems. Arellano and Bond (1991) suggest the use

specifically for the group including Denmark (Table A1.1) as well as for the EU by excluding the group (Table A1.3). Also Germany, UK and Ireland due to their special relations with US investors might have an influence on our overall results. We thus decided to report the results for EU Periphery, excluding Ireland for the period after 1992 and the results for Germany and UK for both time periods (Table A1.2). For a discussion of the results please refer to Appendix 1.

${ }^{5}$ Our sample covers the 15 members of EU during the period under investigation. Due to data limitations on US FDI stocks, Belgium and Luxembourg were unified. That left us with 14 cases. 
of orthogonality conditions between lagged values of the dependent variable and the disturbance terms to obtain additional instruments. They propose the use of a Generalised Method of Moments (GMM) estimator. That being said, the GMM estimator is consistent if and only if there is no second-order serial correlation in the error term of the first-differenced equation.

Two test were used, one for the second order serial correlation of the residuals, and a Sargan test (1958) of over-identifying restrictions assuring the validity of the instruments used. The failure to reject the null hypothesis in both tests provides support for the model specification and the estimation method.

The last issue concerns the high correlation of some variables, especially between the Research and Development variables. We orthogonalised the variables to reduce the high correlation (Greene 1997, p.242).

\section{5.b. The distribution of US FDI in Europe during the last 20 years}

The geography of US investments has considerably changed during the last two decades within the European Union. The whole process is dynamic and this fact is depicted both in the relative importance of selected countries in terms of US investors and in the continuous change in the locational determinants that attract investments. We decided to map US investments at four specific points in time during the last twenty years, i.e.1982, 1990, 1998 and 2002. These four years represent the beginning, the middle and the end of our sample. The four maps clearly demonstrate a structural change in US investment behaviour towards Europe, especially after 1992. According to a recent paper by Buckley (2004), cartography has a lot to offer in international business. This study offers a direct application of cartography methodologies and supports parts of its analysis in the use of maps.

Each map represents the relative US FDI stock as a percentage of total US FDI stock in Europe. The map for 1982 (Figure 1), clearly reveals the existence of two major centres, UK 
and Germany that dominate in terms of relative importance. Furthermore, the rest of the core countries, i.e. France, Belgium-Luxembourg, the Netherlands and at that point of time Italy, form a hub. The rest of the countries that today are part of EU then formed just a periphery in terms of relative position.

\section{Insert Figure 1 here.}

The picture is altered eight years later (Figure 2).

\section{Insert Figure 2 here.}

Three centres now exist. UK and Germany maintain their role and the Netherlands emerges as a significant partner. We observe a more unifying core pattern, whilst Italy seems to deviate and loose relative importance. Similar is the case for Spain and the rest of the rest of the peripheral countries that remain low in their share of US FDI position. This might reflect the effects of the early nineties recession that primarily affected EU peripheral countries.

The third map shows the existence of considerable differences in the late nineties (Figure 3).

\section{Insert Figure 3 here.}

United Kingdom, Germany and the Netherlands remain the centre of US investment position, but the role that the core European countries play is different in each case. The picture exposes the existence of a more dispersed strategy from US investors. France, BelgiumLuxembourg and Italy seem to be of equal importance, whilst Ireland and Spain come forward as significant players from the European periphery. 
This dispersed strategy is further exposed in the early 2000s.

\section{Insert Figure 4 here.}

A very clear case here is Ireland. Ireland achieved the highest level of economic development among all European member states, especially during the nineties. With Gross National Product at the $65 \%$ of EU average in the beginning of the decade, it has reached the EU average in the latest years. This successful pace was accompanied by an increase in inward FDI Stock, which is nowadays the third largest in the EU, relative to each county's GDP. Ireland followed a well-designed strategy towards attracting FDI, which resided in targeting specific MNEs, offering a stable tax environment with one of the lowest corporate tax rates, low cost and skilled labor and an English language speaking setting.

We can draw various conclusions from these four imprints. First of all, the role of UK and Germany is dominant in the relative position of US investors within EU. Secondly, the relative importance of Ireland is not significant until the late nineties. Ireland for the main period does not deviate from the rest of the peripheral countries. Finally, there is clearly a structural change in US investments towards EU the last twenty years. What began mainly as investments in two specific countries, UK and Germany, seems to transform into a more alienated behaviour.

\section{5.c. Results and Interpretation}

Regarding the identification of which factors determine the evolution in the country distribution of US FDI, we answer using a dual approach. The first component is related with the locational determinants of US FDI during the last two decades. The second is related to the linking of those locational determinants with FDI motivations of US firms towards EU countries. 
Breaking up our sample into different regions, within the context of EU, and different time periods, we present evidence on two issues. Firstly, whether the process of integration did affect the FDI motives and, secondly, if the restructuring of FDI was towards further centralization, as a response to the realisation of economies of scale in production, or towards further regionalisation as a response to the increased competition in EU core countries and the need for cost efficiency.

We present our results in the following way. Firstly, we present results for the whole of the EU and then for the EU Core and EU Periphery and then secondly results for two basic time periods. The first period is prior to the realisation of SMP and the second one after the realisation.

\section{5.c.1. EU Total, EU Core and EU Periphery}

Results for the whole of the EU during the last twenty years reveal the importance of agglomeration economies by the positive and statistically significant sign of the FDIP lagged value. Growth of the economy as well as costs of production and labour productivity also emerge as significant factors keeping their hypothesised signs, i.e. positive relation with GDPGR, negative relation with labour cost (LCOST) and positive relation with labour productivity (LPROD) in the business sector. In this respect the results are similar to those obtained by Scaperlanda and Balough (1983), Culem (1988) and Cushman $(1985,1987)$ The positive and statistically significant sign of relative export price index (EXPRI) discloses the intention of US investors to commit to competitive locations through the whole period.

\section{Insert table 2 here}

Results for the EU CORE countries remain the same as for total EU, reflecting the dominant effect of locational factors from EU Core countries in the whole region. In this case, though, 
both labour costs and the competitiveness of local production, captured by the export price index variable, are gaining significance. The cultural variable emerges as a positive and significant factor capturing the US investors' intention to commit resources to culturally similar countries. Our results confirm the positive effect of language as a proxy for culture as already measured by Veugelers (1991). The results nevertheless are dominated by the lagged FDI variable, which is positive and highly statistically significant as in Barell and Pain (1997b).

Results for the EU Periphery for the whole period reveal, on the other hand, a different story. Whilst agglomeration factors still play a significant role, market size as measured by GDP is significant for the first time. This fact is accompanied by the significance of factors capturing labour market conditions. The main difference from EU Core countries comes from the two variables capturing knowledge seeking behaviour. Both of them are negatively signed and statistically significant suggesting that the sole intention of US investors entering peripheral EU markets is to produce mature products and distribute them locally. This picture remains unchanged even if we split up the sample into pre and post 1992 period, supporting the hypothesis that the creation of the Single Market did not relocate investments from core countries to periphery countries within the EU. The actual relocation took place within the EU core. This result validates the theoretical and empirical argumentation of earlier studies (Davies and Weinsten, 1999; Neary, 2002; Egger and Pfaffermayr, 2004)

\section{5.c.2. EU Total, EU Core and EU Periphery (1982-1991 and 1992-2002)}

Our division of the sample to pre and post 1992 period exposes hidden patterns to US investment behaviour before and after the realisation of the Single Market Plan. Only three factors emerge as statistically significant for the whole EU before 1992. Agglomeration economies captured by the FDI lagged value, the absolute size of the European markets and 
the BERD variables are positive and statistically significant, revealing the intention of US investors to capitalise on knowledge creation of EU in total. These results are a mirroring image of the results reported by Gorg and Ruane (1999). In their analysis they conclude that country market size is still an important location factor for FDI attraction. Similar results can be found in various studies (Pain, 1993; Papanastassiou and Pearce, 1990). Results are different for the post 1992 period. Growth of EU countries is positive and statistically significant, reinforcing Barell and Pain's (1999a,b) suggestion that the size of EU economies in the process of European integration is to be determined and not taken as given. Labour cost and labour productivity considerations are also coming forward as strongly determining factors of FDI behaviour. The BERD variable changes sign but is still significant, disclosing a change in the knowledge seeking behaviour of US investors.

\section{Insert table 3 here}

Results for the EU core sub-samples augment the picture. The pre-1992 period is characterised by the search for large, but at the same time slowly growing, markets as shown in the positive and statistically significant sign of GDP and the negatively signed GDPGR. Growth in the local markets increases competition from local firms and thus decreases FDI. Cost considerations are important only when it comes to the actual labour cost and this fact is mirrored in the negative and statistically sign of LCOST. Local competitiveness captured by OPEN acts as a barrier for US investors reinforcing our previous argument on local firms' competition. The main motive for US firms during the pre -1992 period was to get inside the EU, primarily as a reaction to their fears for the creation of the 'Fortress Europe'. In this context competitiveness of the local economy, mirroring the existence of competitive local firms is reducing FDI. 
The realisation of SMP in 1992 changed the behaviour of US investors. Past FDI is still a strong attracting factor but only cost considerations remain important in the investment behaviour. These cost considerations are primarily captured by LCOST which is negatively signed and significant. On the other hand EXPRI becomes positive and significant signalling the investors' behavioural change. The need to find cost effective locations within the context of EU and especially within EU core countries, and from there serve the integrated market is clearly revealed. Our results come into line with Clegg and Scott-Green (1999) who suggest that enterprises appraise positively the process of economic integration.

The impact of SMP in the case of EU Periphery is not different. The pattern of US investment is again changing between pre and post 1992 periods. Agglomeration factors measured by the already established FDI are the most influential factor for both time periods. In the case of EU periphery the existence of previous FDI acts as an evaluation of the local market for future FDI decisions. Both efficiency seeking variables, i.e. labour costs and labour productivity emerge as significant factors in the post- 1992 period. Also both knowledge seeking variables are negatively signed and statistically significant for post -1992 period. An interesting result also comes into the light. Our cultural differences proxy has a negative and statistically significant sign, reinforcing the dominant position of efficiency seeking motives of FDI located in periphery. The FDI undertaken is not catering to the local market, thus MS variables turn out insignificant and the cultural variable is negative. Previous studies (Grosse and Trevino, 1996) have found similar results for cultural proxies.

\section{CONCLUSION}

The purpose of this paper was to present the change in locational determinants of US FDI in the European Union over the last two decades, i.e., 1982-2002 as a result of the ongoing process of European integration. The emphasis was placed on EU-15, as the EU-core 
countries have been the traditional recipients of US FDI since the Second World War and the leaders in a process that led to a unified European market.

One of the main findings of the paper is that despite the process towards a single market, US investors' behaviour gradually changed from a centralised to a decentralised allocation of investment. In the beginning of the period under investigation, two major attracting centres of US FDI have been depicted, i.e. UK and Germany. This changed gradually to a more dispersed interest, especially towards other core European countries. This definitely reflects the positive aspects of European Union integration with respect to the core countries as US investors do not any more locate their investments in UK and Germany but they also consider the rest of the core countries as potential locations. In the late nineties this is further depicted by the varied relative importance of different core countries in the total US FDI in Europe. Similar are the results of Braunerhjelm and Oxelheim (2000). We also find a significant change in investors' behaviour after the creation of the Singe Market. There is, thus, a significant effect of EU integration within core at the beginning of the period under examination and until the full implementation of the Single Market Plan. The picture after the implementation, i.e. in the late nineties and after 2000 is even more optimistic on the effect of the single market towards economic convergence and integration. As one can see from Figures 3 and 4 there is a convergence even between the core and periphery countries with respect to US FDI attraction. That finding though needed further examination in order to identify the specific motives of US investors when investing in different EU countries.

It was the purpose of this paper to provide evidence on that question as well. We explained those location determinants that led to this gradual change and relate them to specific changes within the EU. The MNEs took on a strategic approach to the region. This strategic approach and its change are clearly identified in Pearce and Papanastassiou (1997). The results suggest that the US FDI pattern varies among different groups of countries within the EU. It is 
obvious that US FDI directed to each of the geographical areas, i.e. EU-Core and EUPeriphery, are not determined by a unique set of factors. The process of EU integration, and especially the effect of implementation of Single Market Plan in 1992, changed US investor's behaviour towards EU.

Agglomeration factors, such as already established FDI, market size in some cases, qualified and productive labour capturing the cost efficiency of production in different EU areas and local-firm competitiveness seem to dominate in the process of location choice of US investors.

Different characteristics in the strategic motivations of US MNEs reinforce our findings, not only in regard to the idiosyncratic behaviour of certain location factors but also with respect to the impact of the process of European Integration. Our study reinforces the results obtained by Mold (2003). In our study we use an extended explanatory framework, incorporating in the analysis agglomeration factors and cultural variables. This enables us to give a definite answer to the main question: Did the implementation of the Single Market have an effect on the behaviour of US investors? Yes it had. It further reinforced the integration aspects of the Single Market Plan by revealing and enhancing each market's distinct characteristics and advantages.

In concluding, future research could expand to the new member states that joined the EU in 2004 onwards and could provide sectoral or country-regional evidence, reinforcing this tendency of US investors. Furthermore, it would be interesting to relate US outward FDI with inward US FDI from European Union countries, in order to explore in depth the different factors that drive the relative competitiveness of EU-US. Finally, an examination of the performance of US subsidiaries in their respective host-markets could provide supporting evidence of this change from a microeconomic perspective. 
US OUTWARD FOREIGN DIRECT INVESTMENT IN THE EU AND THE IMPLEMENTATION OF THE SINGLE MARKET:

EMPIRICAL EVIDENCE FROM A COHESIVE FRAMEWORK

TABLES and FIGURES 
US OUTWARD FOREIGN DIRECT INVESTMENT IN THE EU AND THE IMPLEMENTATION OF THE SINGLE MARKET: EMPIRICAL EVIDENCE FROM A COHESIVE FRAMEWORK

Figure 1. US FDI Position 1982 (As percentage of total US position in EU)

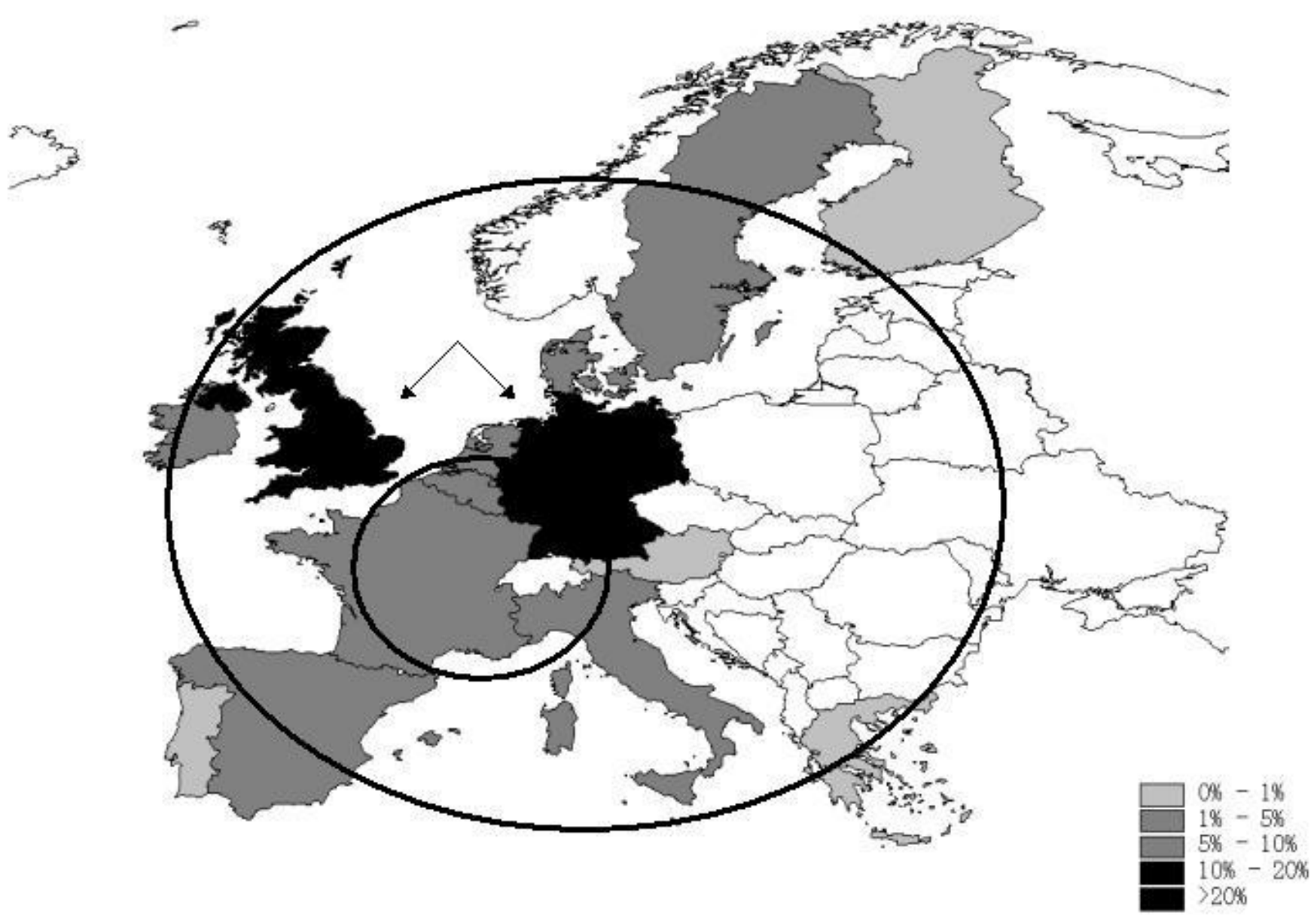


US OUTWARD FOREIGN DIRECT INVESTMENT IN THE EU AND THE IMPLEMENTATION OF THE SINGLE MARKET: EMPIRICAL EVIDENCE FROM A COHESIVE FRAMEWORK

Figure 2. US FDI Position in 1990 (As percentage of total US position in EU)

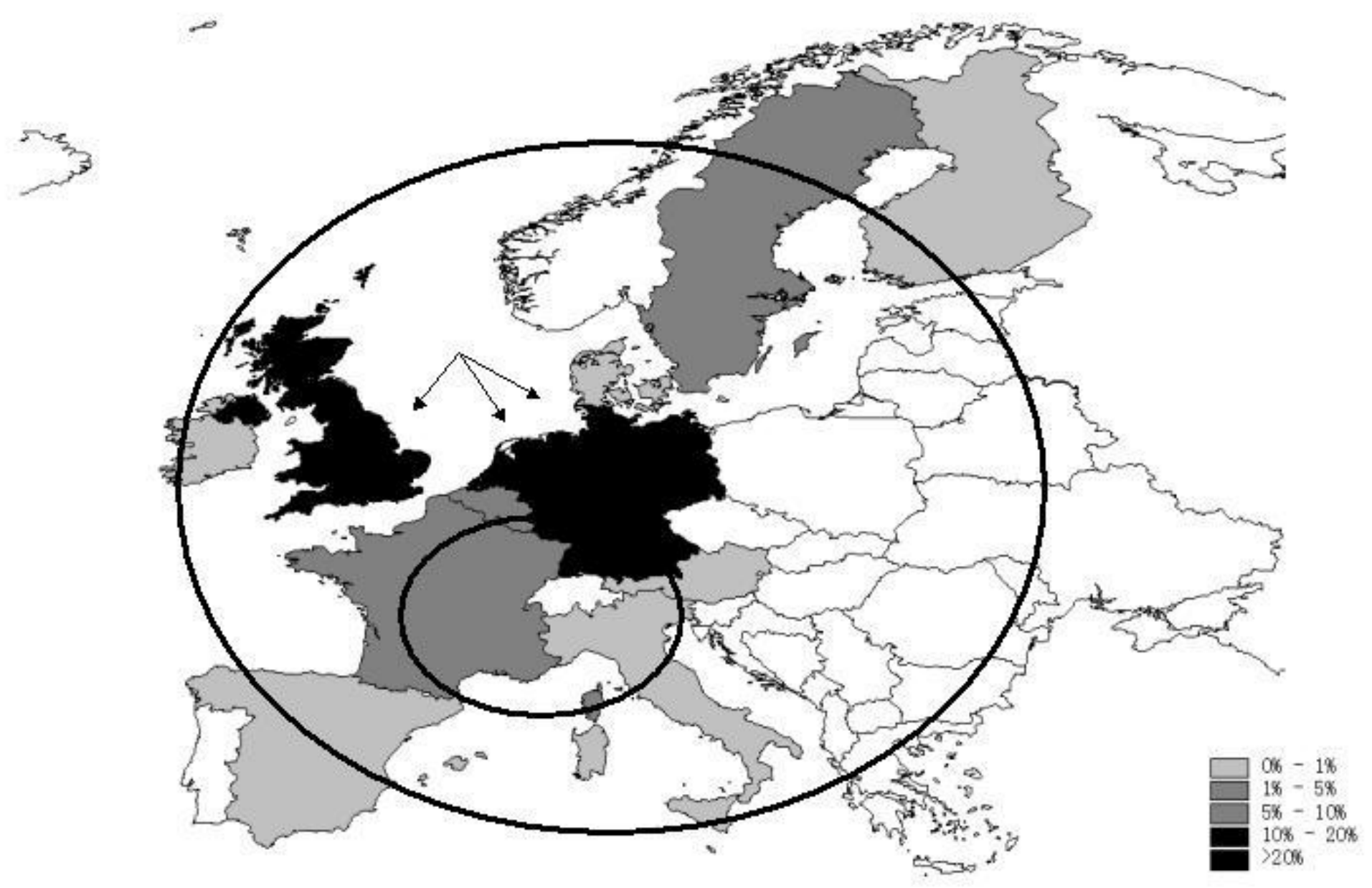


US OUTWARD FOREIGN DIRECT INVESTMENT IN THE EU AND THE IMPLEMENTATION OF THE SINGLE MARKET: EMPIRICAL EVIDENCE FROM A COHESIVE FRAMEWORK

Figure 3. US FDI Position in 1998 (As percentage of total US position in EU)

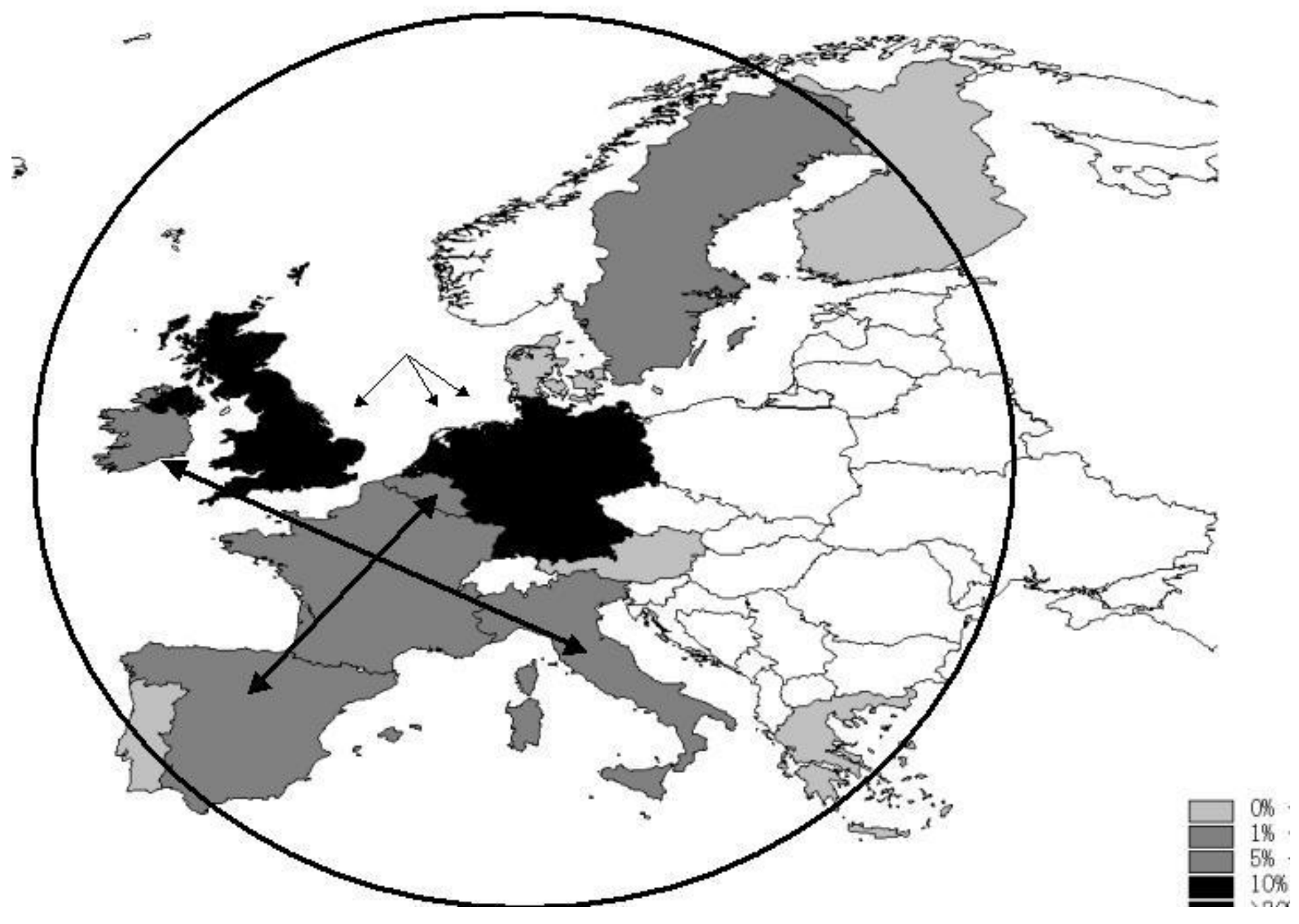


US OUTWARD FOREIGN DIRECT INVESTMENT IN THE EU AND THE IMPLEMENTATION OF THE SINGLE MARKET: EMPIRICAL EVIDENCE FROM A COHESIVE FRAMEWORK

Figure 4. US FDI Position in 2002 (As percentage of total US position in EU)

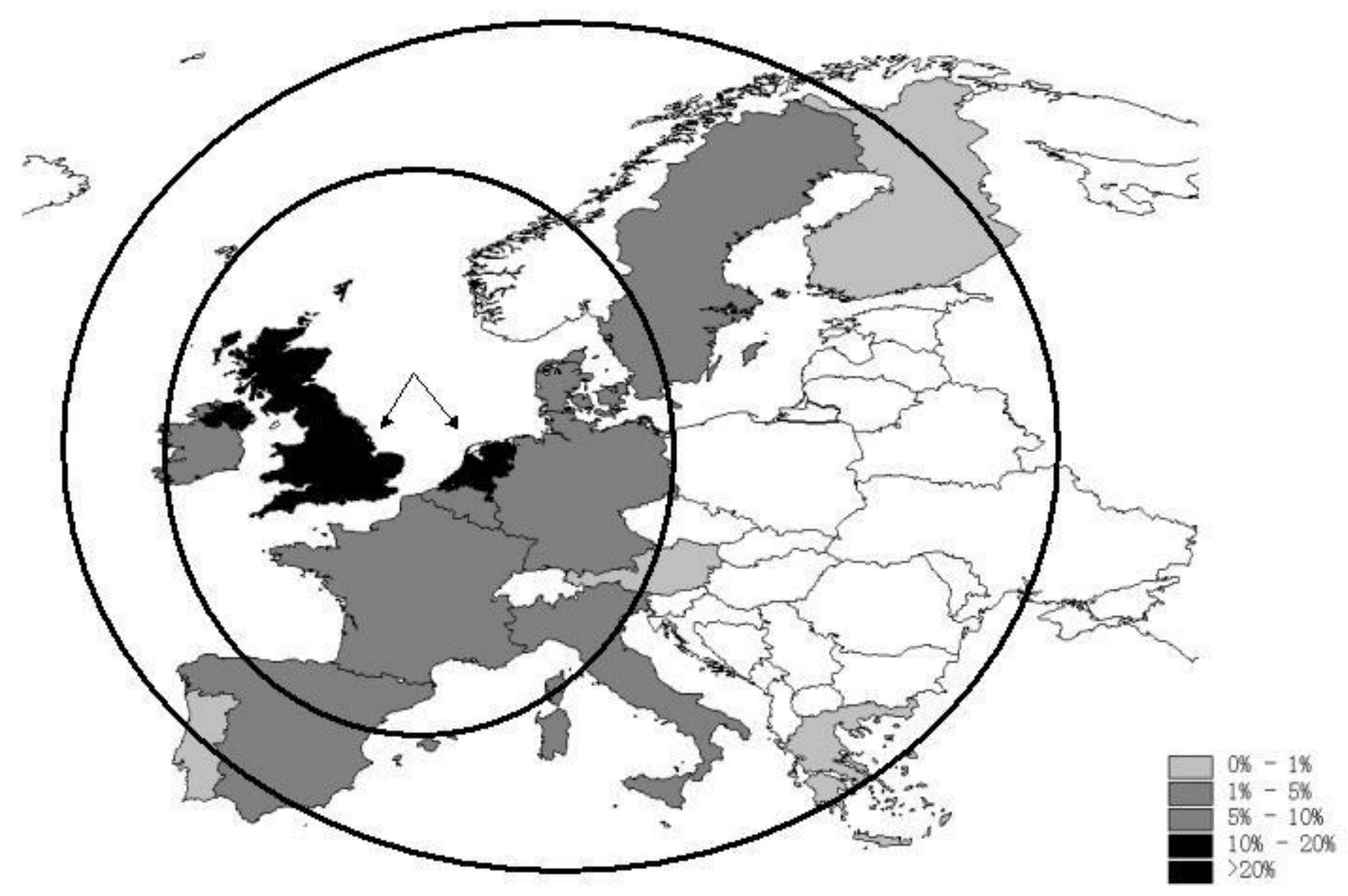




\section{Table 1. Description of Variables}

\begin{tabular}{|c|c|c|}
\hline Variable & Description & Source \\
\hline FDIP & $\begin{array}{l}\text { Direct Investment Position by Country, (Constant } \\
\text { prices and exchange rates 1990), bn. US\$ }\end{array}$ & $\begin{array}{l}\text { OECD International Investment Statistics } \\
\text { Yearbook }\end{array}$ \\
\hline GDP & $\begin{array}{l}\text { GDP, (Constant prices and exchange rates 1990), } \\
\text { bn. US\$ }\end{array}$ & OECD Main Economic Indicators \\
\hline GDPGR & GDP Growth, Percentage change & Authors' Calculations \\
\hline LCOST & $\begin{array}{l}\text { Compensation of Employees, (Constant prices and } \\
\text { exchange rates 1990), US\$ }\end{array}$ & OECD Main Economic Indicators \\
\hline LPROD & Labour Productivity in the business sector, Index & OECD Main Economic Indicators \\
\hline OPEN & $\begin{array}{l}\text { Exports / (Exports+Imports), (Constant prices and } \\
\text { exchange rates 1990), US\$ }\end{array}$ & $\begin{array}{l}\text { OECD International Trade and Competitiveness } \\
\text { Indicators and Authors' Calculations }\end{array}$ \\
\hline EXPRI & $\begin{array}{l}\text { Relative price of exported goods and services, } \\
\text { Index }\end{array}$ & $\begin{array}{l}\text { OECD International Trade and Competitiveness } \\
\text { Indicators }\end{array}$ \\
\hline BERD & $\begin{array}{l}\text { Business Enterprise Expenditure on R\&D - BERD, } \\
\text { (Constant prices and exchange rates 1990), mil. } \\
\text { PPP US\$ }\end{array}$ & OECD Main Science and Technology Indicators \\
\hline TRPAT & Number of "triadic" patent families, (priority year) & OECD Main Science and Technology Indicators \\
\hline CULT & $\begin{array}{l}\text { Percentage of pupil that learn English in Lower and } \\
\text { Upper Secondary Education (ISCED2/3, } \\
\text { International Standard Classification of Education) }\end{array}$ & $\begin{array}{l}\text { Eurydice Database, The information Network on } \\
\text { Education in Europe }\end{array}$ \\
\hline
\end{tabular}


US OUTWARD FOREIGN DIRECT INVESTMENT IN THE EU AND THE IMPLEMENTATION OF THE SINGLE MARKET: EMPIRICAL EVIDENCE FROM A COHESIVE FRAMEWORK

Table 2. EU Total, EU Core and EU Periphery (1982 - 2002)

Dependent Variable: Foreign Direct Investment Stock

Arellano - Bond Dynamic Panel Data estimation with robust standard errors.

\begin{tabular}{|c|c|c|c|}
\hline & EU TOTAL & EU CORE & $\begin{array}{c}\text { EU } \\
\text { PERIPHERY }\end{array}$ \\
\hline FDIP(-1) & $\begin{array}{c}1.0365 * * * \\
(60.51)\end{array}$ & $\begin{array}{c}1.0238 * * * \\
(35.16)\end{array}$ & $\begin{array}{c}0.8767 * * * \\
(25.80)\end{array}$ \\
\hline GDP & $\begin{array}{c}0.0119 \\
(1.09)\end{array}$ & $\begin{array}{c}0.0070 \\
(0.94)\end{array}$ & $\begin{array}{c}0.0132 * * \\
(2.47)\end{array}$ \\
\hline GDPGR & $\begin{array}{c}1.8729 * \\
(1.84)\end{array}$ & $\begin{array}{c}1.0831 \\
(0.73)\end{array}$ & $\begin{array}{c}2.4595 \\
(0.91)\end{array}$ \\
\hline LCOST & $\begin{array}{c}-0.0156 * \\
(-1.78)\end{array}$ & $\begin{array}{c}-0.0123 * \\
(-1.90)\end{array}$ & $\begin{array}{c}-0.0375 * * * \\
(-4.73)\end{array}$ \\
\hline LPROD & $\begin{array}{c}0.0632 * * \\
(2.37)\end{array}$ & $\begin{array}{l}0.0577 * * \\
(2.41)\end{array}$ & $\begin{array}{c}0.2769 * * * \\
(10.48)\end{array}$ \\
\hline OPEN & $\begin{array}{c}1.3327 \\
(0.83)\end{array}$ & $\begin{array}{c}5.7499 \\
(0.03)\end{array}$ & $\begin{array}{c}-9.5218 \\
(-1.06)\end{array}$ \\
\hline EXPRI & $\begin{array}{c}9.8619 * * \\
(2.35)\end{array}$ & $\begin{array}{c}9.0815 * * * \\
(2.68)\end{array}$ & $\begin{array}{c}-2.5983 \\
(-1.29)\end{array}$ \\
\hline BERD & $\begin{array}{c}-1.2051 \\
(-1.16)\end{array}$ & $\begin{array}{c}-1.4687 \\
(-1.55)\end{array}$ & $\begin{array}{c}-5.2979 * * * \\
(-6.20)\end{array}$ \\
\hline TRPAT & $\begin{array}{c}-1.4189 \\
(0.01)\end{array}$ & $\begin{array}{c}-1.2580 \\
(-0.22)\end{array}$ & $\begin{array}{c}-3.8981 * * * \\
(-7.34)\end{array}$ \\
\hline CULT & $\begin{array}{c}1.1350 \\
(1.36) \\
\end{array}$ & $\begin{array}{c}3.6795^{*} \\
(1.91) \\
\end{array}$ & $\begin{array}{c}-2.3855 * * * \\
(-4.79) \\
\end{array}$ \\
\hline Observations & 241 & 160 & 81 \\
\hline Wald test & 560.85 & 398.58 & 60.59 \\
\hline Sargan test & 228.32 & 153.52 & 61.40 \\
\hline $\mathrm{m}_{2}$ & -1.48 & -1.59 & 2.13 \\
\hline
\end{tabular}

-statistics in parenthesis

*** statistically significant at $1 \%, * *$ statistically significant at $5 \%$, * statistically significant at $10 \%$ 
US OUTWARD FOREIGN DIRECT INVESTMENT IN THE EU AND THE IMPLEMENTATION OF THE SINGLE MARKET:

EMPIRICAL EVIDENCE FROM A COHESIVE FRAMEWORK

Table 3. EU Total, EU Core and EU Periphery (1982 - 1991, 1992 - 2002)

Dependent Variable: Foreign Direct Investment Stock

Arellano - Bond Dynamic Panel Data estimation with robust standard errors.

\begin{tabular}{|c|c|c|c|c|c|c|}
\hline & $\begin{array}{l}\text { EU TOTAL } \\
<1992\end{array}$ & $\begin{array}{l}\text { EU TOTAL } \\
>=1992\end{array}$ & $\begin{array}{c}\text { EU CORE } \\
<1992\end{array}$ & $\begin{array}{c}\text { EU CORE } \\
>=1992\end{array}$ & $\begin{array}{c}\text { EU } \\
\text { PERIPHERY }<1992\end{array}$ & $\begin{array}{c}\text { EU } \\
\text { PERIPHERY } \\
>=1992\end{array}$ \\
\hline $\operatorname{FDIP}(-1)$ & $\begin{array}{l}0.9901 * * * \\
(25.21)\end{array}$ & $\begin{array}{c}1.0141 * * * \\
(37.81)\end{array}$ & $\begin{array}{l}0.8070 * * * \\
(6.70)\end{array}$ & $\begin{array}{c}0.9836 * * * \\
(18.67)\end{array}$ & $\begin{array}{c}0.2838 * * \\
(2.40)\end{array}$ & $\begin{array}{c}0.7114 * * * \\
(5.93)\end{array}$ \\
\hline GDP & $\begin{array}{c}0.0314^{*} \\
(1.68)\end{array}$ & $\begin{array}{c}0.0054 \\
(0.37)\end{array}$ & $\begin{array}{c}0.0443 * * \\
(2.39)\end{array}$ & $\begin{array}{c}-0.0026 \\
(-0.14)\end{array}$ & $\begin{array}{c}0.0014 \\
(0.07)\end{array}$ & $\begin{array}{c}-0.0161 \\
(-0.72)\end{array}$ \\
\hline GDPGR & $\begin{array}{c}-1.4653 \\
(-0.85)\end{array}$ & $\begin{array}{c}2.7600 * \\
(1.92)\end{array}$ & $\begin{array}{l}-8.5437 * \\
(-1.89)\end{array}$ & $\begin{array}{c}2.7385 \\
(1.29)\end{array}$ & $\begin{array}{l}9.0379 \\
(0.63)\end{array}$ & $\begin{array}{c}-4.5395 \\
(-0.32)\end{array}$ \\
\hline LCOST & $\begin{array}{c}-0.0078 \\
(-0.92)\end{array}$ & $\begin{array}{c}-0.0123 * \\
(-1.77)\end{array}$ & $\begin{array}{c}-0.0191 * \\
(-1.68)\end{array}$ & $\begin{array}{c}-0.0052 \\
(-0.73)\end{array}$ & $\begin{array}{c}0.0294 \\
(1.44)\end{array}$ & $\begin{array}{c}-0.0151 * * \\
(-2.04)\end{array}$ \\
\hline LPROD & $\begin{array}{c}0.1059 \\
(1.29)\end{array}$ & $\begin{array}{l}0.0590 * * \\
(2.45)\end{array}$ & $\begin{array}{c}0.0855 \\
(1.27)\end{array}$ & $\begin{array}{c}0.0386 \\
(1.45)\end{array}$ & $\begin{array}{c}0.0207 \\
(0.63)\end{array}$ & $\begin{array}{l}0.8003 * * \\
\quad(2.18)\end{array}$ \\
\hline OPEN & $\begin{array}{c}6.1203 \\
(0.59)\end{array}$ & $\begin{array}{c}-2.7268 \\
(-0.14)\end{array}$ & $\begin{array}{c}-9.9930 * * * \\
(-3.04)\end{array}$ & $\begin{array}{c}10.4919 \\
(0.31)\end{array}$ & $\begin{array}{c}5.9224 \\
(1.49)\end{array}$ & $\begin{array}{c}-2.7679 \\
(-1.05)\end{array}$ \\
\hline EXPRI & $\begin{array}{c}-2.2665 \\
(-0.50)\end{array}$ & $\begin{array}{c}1.1531 \\
(1.49)\end{array}$ & $\begin{array}{c}-0.4845 \\
(-1.26)\end{array}$ & $\begin{array}{c}1.7517 * \\
(1.63)\end{array}$ & $\begin{array}{c}3.3380 \\
(1.46)\end{array}$ & $\begin{array}{c}-4.4794 \\
(-0.99)\end{array}$ \\
\hline BERD & $\begin{array}{c}4.2039 * * \\
(2.21)\end{array}$ & $\begin{array}{c}-2.5684 * * \\
(-2.50)\end{array}$ & $\begin{array}{c}1.5253 \\
(0.76)\end{array}$ & $\begin{array}{c}-3.5803 * \\
(-1.87)\end{array}$ & $\begin{array}{c}-2.8815^{*} \\
(-1.76)\end{array}$ & $\begin{array}{c}-8.2066 * * \\
(-2.38)\end{array}$ \\
\hline TRPAT & $\begin{array}{c}1.4996 \\
(0.65)\end{array}$ & $\begin{array}{c}-2.1774 \\
(-0.53)\end{array}$ & $\begin{array}{c}2.9306 \\
(0.16)\end{array}$ & $\begin{array}{c}-5.0992 \\
(-1.41)\end{array}$ & $\begin{array}{c}-2.3001 \\
(-1.47)\end{array}$ & $\begin{array}{c}-7.0654 * * * \\
(-3.21)\end{array}$ \\
\hline CULT & $\begin{array}{c}-0.9947 \\
(-0.02)\end{array}$ & $\begin{array}{c}1.0004 \\
(1.19) \\
\end{array}$ & $\begin{array}{c}1.7632 \\
(0.90) \\
\end{array}$ & $\begin{array}{c}6.4868 \\
(1.34) \\
\end{array}$ & $\begin{array}{c}-6.6906 \\
(-1.66) \\
\end{array}$ & $\begin{array}{c}-1.2903 * * \\
(-2.03) \\
\end{array}$ \\
\hline Observations & 91 & 150 & 61 & 99 & 30 & 51 \\
\hline Wald test & 62.89 & 220.36 & 49.26 & 140.95 & 27.98 & 24.56 \\
\hline Sargan test & 64.39 & 139.57 & 40.03 & 91.66 & 19.06 & 34.79 \\
\hline $\mathrm{m}_{2}$ & 2.93 & -1.67 & 2.71 & -1.70 & -1.37 & 1.56 \\
\hline
\end{tabular}

-s** statistically significant at $1 \%, * *$ statistically significant at $5 \%, *$ statistically significant at $10 \%$ 
US OUTWARD FOREIGN DIRECT INVESTMENT IN THE EU AND THE IMPLEMENTATION OF THE SINGLE MARKET: EMPIRICAL EVIDENCE FROM A COHESIVE FRAMEWORK

\section{REFERENCES}

Aliber, R.Z. (1970) A theory of foreign direct investment, in Kindleberger, C. (editor), The international corporation, Cambridge, Mass: MIT Press.

Amiti, M. (1998a) New trade theories and industrial location in the EU: a survey of evidence, Oxford Review of Economic Policy, Vol. 14, pp. 45-53.

Amiti, M. (1998b) Inter-industry trade in manufactures: Does country size matters?, Journal of International Economics, Vol. 44, pp. 231-255.

Arellano, M., Bond, S. (1991) Some tests of specification for panel data: Monte Carlo evidence and an application to employment equations, Review of Economic Studies, Vol. 58, pp. 277297.

Barrell, R. and Pain, N. (1996) An Econometric Analysis of US Foreign Direct Investment, The Review of Economics and Statistics, LXXVIII, pp. 200-207.

Barrell, R. and Pain, N. (1999a) Trade restraints and Japanese direct investment flows, European Economic Review, Vol. 43, pp. 29-45.

Barrell, R. and Pain, N. (1999b) Domestic Institutions, agglomerations and foreign Direct investment in Europe, European Economic Review, Vol. 43, pp. 925-934.

Behrman, J.N. (1984). Industrial Policies: International Restructuring and Transnationals, Lexington, Lexington MA.

Bellak, C. and Cantwell, J. (2004) Revaluing the capital stock of international production, International Business Review, Vol. 13, pp. 1-18.

Bevan, A., Estrin, S., and Meyer, K., (2004) Foreign investment location and institutional development in transition economies, International Business Review, Vol. 13, pp. 43-64.

Braunerhjelm, P. and Oxelheim, L. (2000) Does Foreign Direct Investment Replace Home Country Investment? The Effect of European Integration on the Location of Swedish Investment, Journal of Common Market Studies, Vol. 38(2), pp. 199-221. 
US OUTWARD FOREIGN DIRECT INVESTMENT IN THE EU AND THE IMPLEMENTATION OF THE SINGLE MARKET:

EMPIRICAL EVIDENCE FROM A COHESIVE FRAMEWORK

Braunerhjelm, P. and Svensson, R. (1996) Host country characteristics and agglomeration in foreign direct investment, Applied Economics, Vol. 28, pp. 833-840.

Buch, C., Kokta, R., and Piazolo, D., (2003) Foreign direct investment in Europe: Is there redirection from the South to the East?, Journal of Comparative Economics, Vol. 31(1), pp. 94-109.

Buckley, P., (2004) Cartography and International Business, International Business Review, Vol. 13, pp. 239-255.

Buckley, P., and Ghauri, P. (2004), Globalisation, Economic Geography and the Strategy of Multinational Enterprises, Journal of International Business Studies, Vol. 35 (2), pp. 8198.

Choi, I. (1999) Testing the Random Walk Hypothesis for Real Exchange Rates, Journal of Applied Econometrics, Vol. 14(3), May-June, pp. 293-308.

Clegg, J. (1996). US Foreign Direct Investment in the EU. The Effects of Market Integration in Perspective, in F. Burton, M. Yamin and S. Young (eds). International Business and Europe in Transition, Macmillan, Basingstoke.

Clegg, J. and Scott-Green, S. (1999) The Determinants of New FDI Capital Flows into the EC: A Statistical Comparison of the USA and Japan, Journal of Common Market Studies, Vol. 37(4), pp. 597-616.

Culem, C. (1988) The locational determinants of direct investments among industrialised countries, European Economic Review, Vol. 21, pp. 885-904.

Cushman, D. O. (1985) Real exchange rate risk, expectations and the level of direct investment, Review of Economics and Statistics, Vol. 67, pp. 297-308.

Cushman, D. O. (1987) The effects of Real Wages and Labour productivity on Foreign Direct Investment, Southern Economic Journal, Vol. 54, pp. 174-185.

D'Arge, R. (1969) Notes on custom unions and foreign direct investment, Economic Journal, Vol. 79, pp. 324-333. 
US OUTWARD FOREIGN DIRECT INVESTMENT IN THE EU AND THE IMPLEMENTATION OF THE SINGLE MARKET: EMPIRICAL EVIDENCE FROM A COHESIVE FRAMEWORK

Davis, D. and Weinstein, D. (1999) Economic Geography and Regional Production Structure: An Empirical Investigation, European Economic Review, Vol. 43(2), pp. 379-407

Dunning, J. (1993) Multinational Enterprises and the global economy, New York: Addison Wesley. Dunning, J. (1997a) The European Internal Market Programme and Inbound Foreign Direct Investment - Part 1, Journal of Common Market Studies, Vol. 35(1), pp. 1-30.

Dunning, J. (1997b) The European Internal Market Programme and Inbound Foreign Direct Investment - Part 2, Journal of Common Market Studies, Vol. 35(2), pp. 189-223.

Dunning, J. (2000) The eclectic paradigm as an envelope for economic and business theories of MNE activities, International Business Review, Vol. 9, pp. 163-190.

Dunning, J. (2002) The Impact of the Completion of the European Internal Market on FDI, in Dunning, J. (editor) Regions, Globalization, and the Knowledge-Based Economy, Oxford : Oxford University Press.

Edwards, R., and Buckley, P. (1998) Choice of location and mode: the case of Australian investors in the UK, International Business Review, Vol. 7, pp. 503-520.

Egger, P., and Pfaffermayr, M. (2004) Foreign Direct Investment and European Integration in the 1990s, The World Economy, Vol. 27(1), pp. 99-110

European Commission, (1996) The impact and effectiveness of the Single Market, Brussels. Eurydice European Unit, (2004) The information network on education in Europe, Brussels.

Filippaios, F., Kottaridi, C., Papanastassiou, M. and Pearce, R. (2004) Empirical evidence on the strategic behaviour of US MNEs within the framework of dynamic differentiated networks, in Jean-Louis Mucchielli and Thierry Mayer (eds), Multinational firms' location and the new economic geography, London: Edward Elgar.

Froot, K.A, and Stein, J.C. (1991) Exchange rates and foreign direct investment: An imperfect capital markets approach, Quarterly Journal of Economics, Vol. 106, pp. 1191-1217.

Goldberg, M., A. (1972) The determinants of US direct investment in the EEC: A comment., American Economic Review, Vol. 62, pp. 692-699. 
US OUTWARD FOREIGN DIRECT INVESTMENT IN THE EU AND THE IMPLEMENTATION OF THE SINGLE MARKET: EMPIRICAL EVIDENCE FROM A COHESIVE FRAMEWORK

Gorg, H. and Ruane, F. (1999) US Investment in EU Member Countries: The Internal Market and

Sectoral Specialization, Journal of Common Market Studies, Vol. 37(2), pp. 333-348.

Greene, W.H. (1997) Econometric Analysis, Prentice-Hall International (UK) Limited, London.

Grosse, R. and Trevino, L.J., (1996) Foreign direct investment in the United States: An analysis by country of origin, Journal of International Business Studies, Vol. 27(1), pp. 139-156.

Hejazi, W., and Pauly. P., (2003), Motivations for FDI and domestic capital formation, Journal of International Business Studies, Vol. 34(3), pp. 282-289.

Hsiao, C. (1986) Analysis of Panel Data, Cambridge University Press.

Im, K.S., Pesaran, M.H., and Shin,Y.(1997) Testing for Unit Roots in Heterogeneous Panels, Manuscript, Department of Applied Economics, University of Cambridge, United Kingdom.

Kogut, B. and Chang, S.J. (1991) Technological Capabilities and Japanese Foreign Direct Investment in the United States, Review of Economics and Statistics, Vol. 73, pp. 401-13.

Markusen, J. (1984) Multinationals, multi-plant economies, and the gains from trade, Journal of International Economics, Vol. 16, pp. 205-226.

Mold, A. (2003) The Impact of the Single Market programme on the Locational Determinants of US Manufacturing Affiliates: An Econometric Analysis, Journal of Common Market Studies, Vol. 41(1), pp. 37-62.

Neary, P. J. (2002) Foreign Direct Investment and the Single Market, The Manchester School, Vol. 70(3), pp. 291-314.

Neven, D. and Siotis, G. (1996) Technology Sourcing and FDI in the EC: An Empirical Evaluation, International Journal of Industrial Organisation, Vol. 14, pp. 543-60.

OECD International Investment Statistics Yearbook, Paris: OECD.Various Issues

OECD Main Economic Indicators, Paris: OECD.Various Issues

OECD Main Science and Technology Indicators, Paris: OECD.Various Issues 
US OUTWARD FOREIGN DIRECT INVESTMENT IN THE EU AND THE IMPLEMENTATION OF THE SINGLE MARKET:

EMPIRICAL EVIDENCE FROM A COHESIVE FRAMEWORK

Pain, N. (1993) An econometric analysis of foreign direct investment in the United Kingdom,

Scottish Journal of Political Economy, Vol. 40(1), pp. 1-23.

Papanastassiou, M. and Pearce, R. (1990) Host country characteristics and the sourcing behaviour of UK manufacturing industry, University of Reading, Department of Economics, Discussion Papers in International Investment and Business Studies, Series B, 2, No. 140.

Papanastassiou, M. and Pearce, R. (1999) Multinationals, Technology and National Competitiveness, Edward Elgar, Cheltenham.

Pearce, R. and Papanastassiou, M. (1997) European Markets and Strategic Roles of Multinational Enterprise Subsidiaries in the UK, Journal of Common Market Studies, Vol. 35(2), pp. 243-266.

Phillips, P.C.B., and Moon, H.R. (2000) Nonstationary Panel Data Analysis: An Overview of Some Recent Developments, Econometric Reviews, Vol. 19, pp. 263-286.

Porter, M.E. (1986) Competition in Global Industries: A Conceptual Framework, in M.E. Porter (ed). Competition in Global Industries, Harvard Business School Press, Boston.

Robson, P. (1987) The Economics of International Integration, London: Allen Unwin $3^{\text {rd }}$ edition.

Sargan, J. D., (1958) The estimation of economic relationships using instrumental variables, Econometrica, Vol. 26, pp. 393-415.

Scaperlanda, A. (1967) The EEC and US foreign direct investment: Some empirical evidence, Economic Journal, Vol. 77, pp. 22-26.

Scaperlanda, A. and Balough, R. (1983) Determinants of US direct investment in the EEC revisited, European Economic Review, Vol. 21, pp. 381-390.

Scaperlanda, A. and Mauer, L., J. (1969) The determinants of US direct investment in EEC, American Economic Review, Vol. 59, pp. 558-568.

Schmitz, A. (1970) The impact of trade blocs on foreign direct investment, Economic Journal, Vol. 80, pp. 724-731. 
US OUTWARD FOREIGN DIRECT INVESTMENT IN THE EU AND THE IMPLEMENTATION OF THE SINGLE MARKET: EMPIRICAL EVIDENCE FROM A COHESIVE FRAMEWORK

Schmitz, A. and Bieri, J. (1972) EEC tariffs and US direct investment, European Economic Review, Vol. 3, pp. 259-270.

Sethi, D., Guisinger, S.E., Phelan, S.E., and Berg, D.M., (2003) Trends in foreign direct investment flows: a theoretical and empirical analysis, Journal of International Business Studies, Vol. 34(4), pp. 315-326

Symeonidis, G. (1996) Innovation, Firm Size and Market Structure: Schumpeterian Hypotheses and some new themes, OECD Economics Department Working Papers, no. 161.

Torstensson, J. (1998) Country size and comparative advantage: An empirical study, Review of World Economy, Vol. 134, pp. 590-612.

Venables, A., J. (1999) Fragmentation and multinational production, European Economic Review, Vol. 43, pp. 935-945.

Vernon, R. (1966) International investment and international trade in the product cycle, Quarterly Journal of Economics, Vol. 80, pp. 190-207.

Veugelers, R. (1991) Locational Determinants and Ranking of Host Countries: an Empirical Assessment, Kyklos, Vol. 44, pp. 363-82

Wallis, K. (1968) The EEC and US foreign investment: some empirical evidence re-examined, Economic Journal, Vol. 78, pp. 717-719.

Wheeler, D. and Mody, A. (1992) International investment location decisions: the case of US firms, Journal of International Economics, Vol. 33, pp. 57-76.

Yannopoulos, G.N. (1990) Foreign Direct Investment and European Integration: The Evidence from the Formative Years of the European Community, Journal of Common Market Studies, Vol. 28, pp. 236-59. 


\section{APPENDICES}

\section{Appendix 1. Special Cases within the EU Context}

The European Union has changed considerably during the years covered by our sample. It is thus important to further split our country sample for two main reasons. First, to check different motives in sub-groups of the EU-core and the EU-periphery and second to verify the robustness of our previous results. The first group of countries we considered is the three Nordic countries. Two of them, namely Sweden and Finland, became EU members in 1995. Those two, accompanied by Denmark form a distinct group of countries. Results for the whole period as well as for the two time periods, pre and post 1992 are presented in table A1.1.

The initial sources of FDI were associated with abundant natural resources. But there are a considerable number of Swedish MNEs that were born before the World War I. The Swedish case shares much in common with the other two Scandinavian countries. Their sources of competitive advantage are the increased Research \& Development expenditures, the fast growth of their MNEs and their decentralized R\&D strategy.

The first striking result is the low significance of agglomeration factors captured by previous FDI stock. Especially when breaking up the sample the FDI turns out insignificant. The second important result is the behaviour of market seeking variables. The absolute size of the market, as measured by the GDP, changes sign between the two periods turning from negative to positive. Rather contradictory are moreover the results coming from the labour market conditions variables. The high level of wages does not divert US investors as we would expect. The existence of high quality and well qualified labour force might be a potential answer to that point. The only two variables that follow the EU-core patterns are those related to the competitiveness of the local economy and the future growth of the market. The factors influencing US FDI decisions, for the period after 1992, resemble closely to those of EU-core countries.

Another group that needs further examination is the group of EU periphery countries especially after 
US OUTWARD FOREIGN DIRECT INVESTMENT IN THE EU AND THE IMPLEMENTATION OF THE SINGLE MARKET:

EMPIRICAL EVIDENCE FROM A COHESIVE FRAMEWORK

1992. The case of Ireland is different from the rest of peripheral countries, especially when it comes

to US investment. Results for the EU Periphery without Ireland for the post 1992 period are presented in table A1.2.

The productivity effects as well as the agglomeration factors do not exist when we exclude Ireland from the Periphery group.

Finally some more different group specifications were tested. First, EU Core without Nordic countries and Austria and second United Kingdom and Germany as a distinct group within EU Core were tested. The results obtained do not change the general picture of US investor behaviour.

Table A1.1. Nordic Countries (Sweden, Finland and Denmark) and Time Periods

\begin{tabular}{|c|c|c|c|}
\hline & NORDIC & NORDIC $<1992$ & NORDIC $>=1992$ \\
\hline $\operatorname{FDIP}(-1)$ & $\begin{array}{c}0.2617 * * * \\
(4.14)\end{array}$ & $\begin{array}{c}1.0783 * * \\
(5.03)\end{array}$ & $\begin{array}{c}-0.1101 * * * \\
(-3.21)\end{array}$ \\
\hline GDP & $\begin{array}{c}-0.0386 * * * \\
(-4.17)\end{array}$ & $\begin{array}{c}-0.0050 \\
(-0.27)\end{array}$ & $\begin{array}{c}-0.0415 * * \\
(-2.70)\end{array}$ \\
\hline GDPGR & $\begin{array}{c}2.8416 * * \\
(2.49)\end{array}$ & $\begin{array}{l}9.7676 * * \\
(3.54)\end{array}$ & $\begin{array}{l}2.4974 * * \\
(2.28)\end{array}$ \\
\hline LCOST & $\begin{array}{c}-0.0005 \\
(-0.12)\end{array}$ & $\begin{array}{c}0.0073 * * * \\
(7.33)\end{array}$ & $\begin{array}{c}0.0359 * * * \\
(3.40)\end{array}$ \\
\hline LPROD & $\begin{array}{l}0.0305 * * \\
(2.65)\end{array}$ & $\begin{array}{c}-0.0231 * * * \\
(-5.03)\end{array}$ & $\begin{array}{c}-0.0265 * * \\
(-2.54)\end{array}$ \\
\hline OPEN & $\begin{array}{c}4.0424 \\
(1.04)\end{array}$ & $\begin{array}{c}-5.7502 \\
(-0.34)\end{array}$ & $\begin{array}{c}4.7050 \\
(1.41)\end{array}$ \\
\hline EXPRI & $\begin{array}{c}5.6440 \\
(0.35)\end{array}$ & $\begin{array}{c}-2.1634 * * * \\
(-7.61)\end{array}$ & $\begin{array}{c}1.5391 \\
(0.83)\end{array}$ \\
\hline BERD & $\begin{array}{c}-2.3477 \\
(-1.14)\end{array}$ & $\begin{array}{l}7.2054 * * \\
(3.74)\end{array}$ & $\begin{array}{c}-1.6558 \\
(-0.69)\end{array}$ \\
\hline TRPAT & $\begin{array}{c}-9.5443 * * * \\
(-2.93)\end{array}$ & $\begin{array}{c}-2.7202 \\
(-0.39)\end{array}$ & $\begin{array}{c}-6.7624 \\
(-1.65)\end{array}$ \\
\hline CULT & $\begin{array}{c}-2.1969 \\
(-1.06) \\
\end{array}$ & $\begin{array}{c}1.2714^{*} \\
(2.47)\end{array}$ & $\begin{array}{c}-3.6713 \\
(-1.60) \\
\end{array}$ \\
\hline Observations & 46 & 13 & 33 \\
\hline Wald test & 11.32 & 11.56 & 8.56 \\
\hline Sargan test & 37.71 & 2.16 & 25.84 \\
\hline $\mathrm{m}_{2}$ & -0.95 & 0.57 & -2.42 \\
\hline
\end{tabular}

$\mathrm{t}$-statistics in parenthesis

$* * *$ statistically significant at $1 \%, * *$ statistically significant at $5 \%, *$ statistically significant at $10 \%$ 
US OUTWARD FOREIGN DIRECT INVESTMENT IN THE EU AND THE IMPLEMENTATION OF THE SINGLE MARKET: EMPIRICAL EVIDENCE FROM A COHESIVE FRAMEWORK

Table A1.2. Special Groups. EU Periphery after 1992 with Ireland excluded, UK and Germany only for the two time periods.

\begin{tabular}{|c|c|c|c|}
\hline & $\begin{array}{c}\text { EU PERIPHERY > }=1992 \text { (NOT } \\
\text { IRELAND) }\end{array}$ & $\begin{array}{l}\text { GERMANY \& } \\
\text { UK }<1992\end{array}$ & $\begin{array}{l}\text { GERMANY \& } \\
\text { UK }>=1992\end{array}$ \\
\hline $\operatorname{FDIP}(-1)$ & $\begin{array}{c}0.2558 \\
(0.86)\end{array}$ & $\begin{array}{c}0.6423 * * * \\
(5.25)\end{array}$ & $\begin{array}{c}0.5851 * * * \\
(22.64)\end{array}$ \\
\hline GDP & $\begin{array}{l}0.0513 * * * \\
(6.13)\end{array}$ & $\begin{array}{c}0.0906^{*} \\
(1.84)\end{array}$ & $\begin{array}{c}0.0416 * * * \\
(4.88)\end{array}$ \\
\hline GDPGR & $\begin{array}{c}2.0429 \\
(1.26)\end{array}$ & $\begin{array}{c}-6.3327 \\
(-1.02)\end{array}$ & $\begin{array}{c}-5.0590 * \\
(-1.96)\end{array}$ \\
\hline LCOST & $\begin{array}{c}0.0111 \\
(0.27)\end{array}$ & $\begin{array}{c}-0.1634 * * * \\
(-47.66)\end{array}$ & $\begin{array}{c}-0.3126^{* * * *} \\
(-3.84)\end{array}$ \\
\hline LPROD & $\begin{array}{c}-1.1135^{*} \\
(-1.79)\end{array}$ & $\begin{array}{c}-0.4761 \\
(-0.29)\end{array}$ & $\begin{array}{c}2.2108 \\
(1.08)\end{array}$ \\
\hline OPEN & $\begin{array}{c}9.3456 \\
(0.53)\end{array}$ & $\begin{array}{c}-1.7622 \\
(-0.83)\end{array}$ & $\begin{array}{c}-4.1776^{* * * *} \\
(-4.86)\end{array}$ \\
\hline EXPRI & $\begin{array}{l}-7.7588 * \\
(-1.83)\end{array}$ & $\begin{array}{l}3.9323 * * * \\
(2.89)\end{array}$ & $\begin{array}{l}8.0258 * * * \\
(26.82)\end{array}$ \\
\hline BERD & $\begin{array}{c}-1.2889 \\
(-0.68)\end{array}$ & $\begin{array}{c}-2.4961 * * \\
(-2.08)\end{array}$ & $\begin{array}{c}-3.7134 * * * \\
(-6.25)\end{array}$ \\
\hline TRPAT & $-1.8757 *$ & -2.2836 & $-6.9318 * * *$ \\
\hline CULT & $\begin{array}{c}1.0431 \\
(0.97)\end{array}$ & $\begin{array}{l}2.0828 * * * \\
(13.59)\end{array}$ & $\begin{array}{l}3.9233 * * * \\
(9.64)\end{array}$ \\
\hline Observations & 40 & 27 & 30 \\
\hline Wald test & 20.96 & 18.56 & 23.20 \\
\hline Sargan test & 32.52 & 13.83 & 14.39 \\
\hline $\mathrm{m}_{2}$ & -1.73 & -0.70 & -0.45 \\
\hline
\end{tabular}

$\mathrm{t}$-statistics in parenthesis

*** statistically significant at $1 \%, * *$ statistically significant at $5 \%, *$ statistically significant at $10 \%$ 
US OUTWARD FOREIGN DIRECT INVESTMENT IN THE EU AND THE IMPLEMENTATION OF THE SINGLE MARKET: EMPIRICAL EVIDENCE FROM A COHESIVE FRAMEWORK

Table A1.3. EU Core excluding Nordic countries (Sweden, Finland and Denmark) and Time Periods

\begin{tabular}{|c|c|c|c|}
\hline & $\begin{array}{c}\text { EU CORE (NOT } \\
\text { NORDIC) }\end{array}$ & $\begin{array}{l}\text { EU CORE (NOT } \\
\text { NORDIC) }<1992\end{array}$ & $\begin{array}{c}\text { EU CORE (NOT } \\
\text { NORDIC) }>=1992\end{array}$ \\
\hline $\operatorname{FDIP}(-1)$ & $\begin{array}{c}1.0136 * * * \\
(22.99)\end{array}$ & $\begin{array}{c}0.8210 * * * \\
(4.70)\end{array}$ & $\begin{array}{c}0.9361 * * * \\
(10.13)\end{array}$ \\
\hline GDP & $\begin{array}{c}0.0578 * \\
(1.69)\end{array}$ & $\begin{array}{c}0.0694 * * * \\
(3.67)\end{array}$ & $\begin{array}{c}0.0310 \\
(0.83)\end{array}$ \\
\hline GDPGR & $\begin{array}{c}-9.1592 \\
(-0.30)\end{array}$ & $\begin{array}{c}-1.0065^{*} \\
(-1.89)\end{array}$ & $\begin{array}{c}1.7211 \\
(0.52)\end{array}$ \\
\hline LCOST & $\begin{array}{c}-0.0804 * \\
(-1.66)\end{array}$ & $\begin{array}{c}-0.0732 * * \\
(-2.56)\end{array}$ & $\begin{array}{c}-0.0825 \\
(-1.25)\end{array}$ \\
\hline LPROD & $\begin{array}{c}-0.0886 \\
(-0.47)\end{array}$ & $\begin{array}{c}0.1196 \\
(0.40)\end{array}$ & $\begin{array}{c}-0.1049 \\
(-0.28)\end{array}$ \\
\hline OPEN & $\begin{array}{c}3.1406 \\
(0.95)\end{array}$ & $\begin{array}{c}-1.2636 * * * \\
(-6.26)\end{array}$ & $\begin{array}{c}-3.0458 \\
(-0.34)\end{array}$ \\
\hline EXPRI & $\begin{array}{l}1.5645 * * \\
(2.17)\end{array}$ & $\begin{array}{c}4.6224 \\
(0.15)\end{array}$ & $\begin{array}{c}3.2904 * * * \\
(2.88)\end{array}$ \\
\hline BERD & $\begin{array}{c}-2.5689 \\
(-1.04)\end{array}$ & $\begin{array}{c}1.2404 \\
(0.29)\end{array}$ & $\begin{array}{c}-8.9607 \\
(-1.46)\end{array}$ \\
\hline TRPAT & -1.8258 & -1.2605 & -9.7979 \\
\hline CULT & $\begin{array}{c}4.0460 * * \\
(2.30)\end{array}$ & $\begin{array}{c}1.7089 \\
(0.82) \\
\end{array}$ & $\begin{array}{c}1.1243 * * * \\
(1.83)\end{array}$ \\
\hline Observations & 114 & 48 & 66 \\
\hline Wald test & 283.65 & 35.62 & 90.53 \\
\hline Sargan test & 105.54 & 60.35 & 57.10 \\
\hline $\mathrm{m}_{2}$ & -1.61 & 1.54 & -1.53 \\
\hline
\end{tabular}

t-statistics in parenthesis

$* * *$ statistically significant at $1 \%, * *$ statistically significant at $5 \%, *$ statistically significant at $10 \%$ 
US OUTWARD FOREIGN DIRECT INVESTMENT IN THE EU AND THE IMPLEMENTATION OF THE SINGLE MARKET:

EMPIRICAL EVIDENCE FROM A COHESIVE FRAMEWORK

Table A1.4. EU Core excluding Nordic countries (Sweden, Finland and Denmark) and Austria

\begin{tabular}{|c|c|c|c|}
\hline & $\begin{array}{c}\text { EU CORE NOT } \\
\text { NOR \& AUSTRIA }\end{array}$ & $\begin{array}{c}\text { EU CORE NOT NOR \& } \\
\text { AUSTRIA<1992 }\end{array}$ & $\begin{array}{c}\text { EU CORE NOT NOR \& } \\
\text { AUSTRIA }>=1992\end{array}$ \\
\hline FDIP(-1) & $\begin{array}{c}1.0029 * * * \\
(24.12)\end{array}$ & $\begin{array}{c}0.7707 * * * \\
(4.29)\end{array}$ & $\begin{array}{c}0.8847 * * * \\
(7.89)\end{array}$ \\
\hline GDP & $\begin{array}{c}0.0501 \\
(1.47)\end{array}$ & $\begin{array}{c}0.0759 * * * \\
(3.64)\end{array}$ & $\begin{array}{c}0.0262 \\
(1.09)\end{array}$ \\
\hline GDPGR & $\begin{array}{l}-7.9761 \\
(-0.25)\end{array}$ & $\begin{array}{c}-1.1521 * \\
(-1.97)\end{array}$ & $\begin{array}{c}1.4639 \\
(0.75)\end{array}$ \\
\hline LCOST & $\begin{array}{c}-0.0661 \\
(-1.43)\end{array}$ & $\begin{array}{c}-0.0762 * * * \\
(-2.89)\end{array}$ & $\begin{array}{c}-0.0749 \\
(-1.34)\end{array}$ \\
\hline LPROD & $\begin{array}{c}0.1325 \\
(0.69)\end{array}$ & $\begin{array}{c}0.0300 \\
(0.11)\end{array}$ & $\begin{array}{c}0.5276 \\
(0.51)\end{array}$ \\
\hline OPEN & $\begin{array}{c}1.6082 \\
(0.44)\end{array}$ & $\begin{array}{c}-1.2668 * * * \\
(-5.46)\end{array}$ & $\begin{array}{c}-7.1311 \\
(-0.62)\end{array}$ \\
\hline EXPRI & $\begin{array}{c}1.1674 \\
(1.44)\end{array}$ & $\begin{array}{c}1.5356 \\
(0.25)\end{array}$ & $\begin{array}{c}3.1624^{*} \\
(1.81)\end{array}$ \\
\hline BERD & $\begin{array}{c}-1.1037 \\
(-0.49)\end{array}$ & $\begin{array}{c}-2.4849 \\
(-0.06)\end{array}$ & $\begin{array}{c}-7.6991 \\
(-0.90)\end{array}$ \\
\hline TRPAT & $\begin{array}{c}-6.4486 \\
(-0.08)\end{array}$ & $\begin{array}{c}-1.1398 \\
(-0.63)\end{array}$ & $\begin{array}{c}-1.0261 \\
(-0.65)\end{array}$ \\
\hline CULT & $\begin{array}{c}5.2813 * * * \\
(3.13) \\
\end{array}$ & $\begin{array}{c}2.2031 \\
(0.89) \\
\end{array}$ & $\begin{array}{c}1.7930 * * \\
(2.33)\end{array}$ \\
\hline Observations & 95 & 40 & 55 \\
\hline Wald test & 206.56 & 28.69 & 68.36 \\
\hline Sargan test & 86.72 & 23.14 & 46.74 \\
\hline $\mathrm{m}_{2}$ & -1.44 & 2.71 & -1.27 \\
\hline
\end{tabular}

$\mathrm{t}$-statistics in parenthesis

*** statistically significant at $1 \%, * *$ statistically significant at $5 \%, *$ statistically significant at $10 \%$ 
US OUTWARD FOREIGN DIRECT INVESTMENT IN THE EU AND THE IMPLEMENTATION OF THE SINGLE MARKET: EMPIRICAL EVIDENCE FROM A COHESIVE FRAMEWORK

Appendix 2. Formulation of the Im, Pesharan, Shin test (1997) and Stationarity Results

Before proceeding with the empirical evidence, it is important to clarify vital technical issues. The first issue concerns the stationarity of time series. Although recent econometric literature (Philips and Moon, 2000) shows that when using panel datasets the regressions are usually not spurious, because the cross sectional element removes all the noise, the majority of these studies refer to large datasets both on the cross sectional and the time series dimension. In this study, neither the time span nor the cross-section dimension of the dataset used are large enough to provide us with confidence that we do not have any kind of problem, and thus we decided to test for unit roots as a first step. Testing for unit roots in panels is relatively recent and both the power as well as the accuracy of different tests is still at the heart of the research agenda. We decided to test for the existence of a unit root in our economic series, using the Im, Pesaran Shin (1997) test (IPS) ${ }^{6}$. This test was mainly chosen for two reasons. Firstly, it allows for heterogeneity across the individual $i$ 's, in our case countries, and moreover the IPS t-bar test has the most stable size amongst different panel unit roots sets (Choi, 1999).

\section{a. Test Formulation}

More precisely the test is constructed as follows:

Consider the model:

$$
y_{i t}=\rho_{i} y_{i t-1}+z_{i t}^{\prime} \gamma+u_{i t}, i=1, \ldots, N ; t=1, \ldots, T
$$

Where $\mathrm{z}_{\mathrm{it}}$ is the fixed effects and $u_{i t}=\sum_{j=1}^{p_{i}} \phi_{i j} u_{i t-j}+\varepsilon_{i t}(2)$, that means that $\mathrm{u}_{\mathrm{it}}$ are serially correlated with different serial correlation properties across cross-sectional units. We combine the two equations, (1) and (2) and we get:

$$
y_{i t}=\rho_{i} y_{i t-1}+\sum_{j=1}^{p_{i}} \phi_{i j} \Delta y_{i t-j}+z_{i t}^{\prime} \gamma+\varepsilon_{i t}(3)
$$

The null hypothesis is $H_{0}: \rho_{i}=1$

\footnotetext{
${ }^{6}$ The construction of IPS test is presented in Appendix 2.
} 
US OUTWARD FOREIGN DIRECT INVESTMENT IN THE EU AND THE IMPLEMENTATION OF THE SINGLE MARKET:

EMPIRICAL EVIDENCE FROM A COHESIVE FRAMEWORK

For all $\mathrm{i}$ and the alternative is $H_{\alpha}: \rho_{i}<1$ for at least one $\mathrm{i}$. The IPS t-bar statistic is defined as the average of the individual Augmented Dickey Fuller (ADF) statistic as:

$\bar{t}=\frac{1}{N} \sum_{i=1}^{N} t_{\rho_{i}}$ where $t_{\rho_{i}}$ is the individual t-statistic of testing the $\mathrm{H}_{0}$ in (3). Using some manipulation ${ }^{7}$ we get that:

$t_{I P S}=\frac{\sqrt{N}\left(\bar{t}-E\left[t_{i T} \mid \rho_{i}=1\right]\right)}{\sqrt{\operatorname{Var}\left[t_{i T} \mid \rho_{i}=1\right]}} \Rightarrow N(0,1)$

The values for $E\left[t_{i T} \mid \rho_{i}=1\right]$ and $\operatorname{Var}\left[t_{i T} \mid \rho_{i}=1\right]$ have been computed by IPS using simulations techniques for different values of $\mathrm{T}$ and $\mathrm{p}_{\mathrm{i}}$ 's.

\section{b. Stationarity tests}

The results of the IPS test for the full sample and the two European sub-samples presented in tables 4 to 6 show no evidence of the existence of a unit root.

\section{Insert table A2.1 here}

Insert table A2.2 here

\section{Insert table A2.3 here}

The results showed that we cannot accept the null hypothesis of the existence of a unit root and so we proceeded to the second stage using Arellano Bond (1991) dynamic panel fixed effects estimation methods. The aim of this second step was to shed some light on the locational determinants of US FDI during the period 1982-2002.

\footnotetext{
${ }^{7}$ Using the properties of the residuals and the Lindeberg-Levy central limit theorem.
} 
Table A2.1. Im, Pesharan, Shin Unit Root Test (EU Sample)

\begin{tabular}{|c|c|c|c|c|c|}
\hline Series & Lags & t-bar & Psi (t-bar) & Prob. $^{8}$ & Obs. \\
\hline FDIP & 1 & 1.18 & 9.63 & 0.00 & 271 \\
\hline GDP & 1 & -0.53 & 3.98 & 0.00 & 271 \\
\hline GDPGR & 1 & -2.31 & -3.09 & 0.00 & 257 \\
\hline LCOST & 1 & -0.47 & 3.90 & 0.00 & 271 \\
\hline LPROD & 1 & 0.56 & 8.37 & 0.00 & 271 \\
\hline OPEN & 2 & -1.66 & -0.87 & 0.19 & 262 \\
\hline EXPRI & 4 & -1.16 & 0.74 & 0.22 & 244 \\
\hline BERD & 3 & -1.11 & 1.25 & 0.11 & 253 \\
\hline TRPAT & 4 & -1.19 & 0.60 & 0.27 & 244 \\
\hline CULT & 6 & -1.67 & -1.36 & 0.08 & 226 \\
\hline
\end{tabular}

Table A2.2. Im, Pesharan, Shin Unit Root Test (EU Core Sample)

\begin{tabular}{|c|c|c|c|c|c|}
\hline Series & Lags & t-bar & Psi (t-bar) & Prob. ${ }^{9}$ & Obs. \\
\hline FDIP & 1 & 1.39 & 8.27 & 0.00 & 174 \\
\hline GDP & 1 & -0.53 & 3.17 & 0.00 & 174 \\
\hline GDPGR & 1 & -2.55 & -3.24 & 0.00 & 165 \\
\hline LCOST & 2 & 0.19 & 4.85 & 0.00 & 168 \\
\hline LPROD & 1 & 0.54 & 6.62 & 0.00 & 174 \\
\hline OPEN & 3 & -1.10 & 1.03 & 0.15 & 162 \\
\hline EXPRI & 3 & -1.80 & -1.11 & 0.13 & 162 \\
\hline BERD & 2 & -2.07 & -1.98 & 0.02 & 168 \\
\hline TRPAT & 2 & -1.64 & -0.63 & 0.27 & 168 \\
\hline CULT & 6 & -1.54 & -0.72 & 0.26 & 144 \\
\hline
\end{tabular}

Table A2.3. Im, Pesharan, Shin Unit Root Test (EU Periphery Sample)

\begin{tabular}{|c|c|c|c|c|c|}
\hline Series & Lags & t-bar & Psi (t-bar) & Prob. ${ }^{10}$ & Obs. \\
\hline FDIP & 1 & -0.18 & 2.88 & 0.00 & 100 \\
\hline GDP & 1 & -0.26 & 3.02 & 0.00 & 100 \\
\hline GDPGR & 2 & -2.58 & -2.61 & 0.01 & 95 \\
\hline LCOST & 1 & 0.46 & 4.26 & 0.00 & 100 \\
\hline LPROD & 1 & -0.06 & 3.51 & 0.00 & 100 \\
\hline OPEN & 4 & -1.68 & -0.72 & 0.23 & 85 \\
\hline EXPRI & 2 & -2.18 & -1.74 & 0.04 & 95 \\
\hline BERD & 1 & -1.27 & 0.59 & 0.28 & 100 \\
\hline TRPAT & 1 & -1.36 & 0.34 & 0.37 & 100 \\
\hline CULT & 7 & -0.96 & 0.64 & 0.73 & 100 \\
\hline
\end{tabular}

\footnotetext{
${ }^{8}$ The critical values for $10 \%, 5 \%$ and $1 \%$ are $-1.82,-1.90$ and -2.07 respectively.

${ }^{9}$ The critical values for $10 \%, 5 \%$ and $1 \%$ are $-1.95,-2.08$ and -2.32 respectively.

${ }^{10}$ The critical values for $10 \%, 5 \%$ and $1 \%$ are $-2.04,-2.18$ and -2.46 respectively.
} 
US OUTWARD FOREIGN DIRECT INVESTMENT IN THE EU AND THE IMPLEMENTATION OF THE SINGLE MARKET: EMPIRICAL EVIDENCE FROM A COHESIVE FRAMEWORK

Appendix 3. Basic statistics and Correlation matrix

Basic Statistics

\begin{tabular}{|l|r|r|r|r|r|}
\hline Variable & N & Mean & Std. Dev. & Min & Max \\
\hline FDIP & 291 & 20368 & 37473 & 87 \\
GDP & 294 & 541050 & 551487 & 39144 \\
GDPGR & 280 & 0.027 & 0.023 & -0.064 \\
LCOST & 275 & 299725 & 309330 & 3138 \\
LPROD & 294 & 83412 & 121311 & 0.156 \\
OPEN & 294 & 0.504 & 0.036 & 10996 \\
EXPRI & 294 & 111.269 & 11.965 & 0.403 \\
BERD & 294 & 5892 & 7801 & 80.934 \\
TRPAT & 291 & 773 & 1212 & 53 \\
CULT & 294 & 88.72 & 17.54 & 0.631 \\
\end{tabular}

Correlation Table

\begin{tabular}{|c|c|c|c|c|c|c|c|c|c|c|}
\hline & FDIP & GDP & GDPGR & LCOST & LPROD & COMP & EXPRI & BERD & TRPAT & CULT \\
\hline FDIP & 1.00 & & & & & & & & & \\
\hline GDP & $0.47 *$ & 1.00 & & & & & & & & \\
\hline GDPGR & 0.01 & -0.09 & 1.00 & & & & & & & \\
\hline LCOST & $0.23^{*}$ & $0.56^{*}$ & $-0.14 *$ & 1.00 & & & & & & \\
\hline LPROD & $-0.16^{*}$ & $-0.26^{*}$ & -0.08 & $0.60 *$ & 1.00 & & & & & \\
\hline OPEN & 0.05 & 0.07 & 0.11 & $0.23 *$ & $0.28 *$ & 1.00 & & & & \\
\hline EXPRI & $-0.26 *$ & -0.18 & 0.01 & -0.12 & -0.05 & $-0.46^{*}$ & 1.00 & & & \\
\hline BERD & $-0.55^{*}$ & $-0.25^{*}$ & 0.03 & -0.06 & $0.19 *$ & -0.07 & 0.01 & 1.00 & & \\
\hline TRPAT & $-0.36^{*}$ & $-0.49 *$ & -0.01 & $-0.17 *$ & $0.12 *$ & 0.02 & $0.28 *$ & -0.08 & 1.00 & \\
\hline CULT & $0.37 *$ & $0.09 *$ & $0.24 *$ & $0.26^{*}$ & $0.21 *$ & $0.24^{*}$ & -0.06 & 0.04 & $-0.17 *$ & 1.00 \\
\hline
\end{tabular}

$*$ denotes significance at $5 \%$ 